Ethos: Jurnal Penelitian dan Pengabdian kepada Masyarakat, Vol 8, No.1, Juni 2019: 95-104

\title{
Gerakan Satu Rumah Satu Jumantik (SARUJU) di Kampung Pelita Medika II BULUH CINA KABUPATEN KAMPAR
}

\author{
${ }^{1}$ Suri Dwi Lesmana, ${ }^{2}$ Elva Susanty, ${ }^{3}$ Dedi Afandi
}

${ }^{1,2,3}$ Universitas Riau, Bandung, Riau, Indonesia

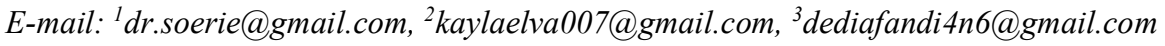

\begin{abstract}
Dengue hemorrhagic fever (DHF) is a very serious health problem, especially in Indonesia. Dengue hemorrhagic fever is caused by the Dengue Virus transmitted by Aedes aegypti mosquito vector as the actual vector and Aedes albopictus as the potential vector. Various efforts have been implemented but the incidence of dengue is still high. One of the spearheads in eradicating DHF is to break the chain of transmission through the Mosquito Nest Eradication program. To support the PSN program, Jumantik Monitors are formed in each village. However, due to limited resources, monitoring by jumantik has not been entirely successful. Based on this, it is necessary to consider the effectiveness of the implementation of this jumantik through the SARUJU program, namely the one jumantik per house program. Jumantik was a medical student at the University of Riau who became a foster child in village namely Pelita Medika Buluh Cina Village. Jumantik has the duty to monitor the existence and density of larvae, implement PSN and appoint a second jumantik who is a member of the original family. Through the first stage larvae survey, there was a high rate of larvae density. Through Saruju activities, it is expected that a decrease in larvae density will reduce the incidence of DHF.
\end{abstract}

Keywords: Dengue hemorrhagic fever, Saruju, Jumantik

\begin{abstract}
Abstrak. Demam berdarah dengue (DBD) merupakan masalah kesehatan yang sangat serius, terutama di Indonesia. Demam berdarah dengue disebabkan oleh Virus Dengue dengan perantaraan vektor nyamuk Aedes aegypti sebagai vektor aktual dan Aedes albopictus sebagai vektor potensial. Berbagai upaya telah dilakukan pemerintah melalui program yang telah dilaksanakan, namum kejadian DBD masih tetap tinggi. Salah satu ujung tombak pemberantasan DBD adalah dengan memutus rantai penularan melalui program Pemberantasan Sarang Nyamuk (PSN). Namun demikian program tersebut tidak dilaksanakan secara efektif pada berbagai lapisan masyarakat. Untuk menunjang program PSN dibentuklah Juru Pemantau Jentik (Jumantik) pada tiap kelurahan. Namun demikian karena keterbatasan sumber daya menyebabkan pemantauan oleh jumantik tidak berhasil Berdasarkan hal tersebut perlu dipikirkan efektifitas pelaksanaan jumantik ini melalui gerakan SARUJU yaitu gerakan satu rumah satu jumantik. Jumantik berasal dari mahasiswa Fakultas Kedokteran UNRI yang merupakan anak asuh dari Desa Binaan Kampung Pelita Medika II Buluh Cina. Jumantik berkewajiban memantau keberadaan dan kepadatan jentik di rumahnya, melaksanakan PSN, serta menunjuk dan mengedukasi jumantik kedua yang merupakan anggota keluarga asli. Berdasarkan survey jentik didapatkan kepadatan jentik yang tinggi di daerah tersebut. Melalui kegiatan saruju diharapkan kejadian DBD di daerah tersebut dapat ditekan.
\end{abstract}

Kata kunci: Demam berdarah dengue, Saruju, Jumantik 


\section{Pendahuluan}

Demam berdarah dengue (DBD) merupakan masalah kesehatan yang sangat penting, terutama di Indonesia. Demam berdarah dengue adalah penyakit yang disebabkan oleh Virus Dengue dan merupakan penyakit infeksi virus yang paling cepat menyebar di dunia ( Hoedojo R, 2008). Penyakit ini dapat menyebabkan kematian karena perdarahan dan juga gangguan hemodinamika ( Suhendro, 2014). Demam berdarah dengue ditularkan melalui nyamuk Genus Aedes. Nyamuk Aedes aegypti (Ae. Aegypti) merupakan vektor utama, sedangkan Aedes albopictus (Ae. Albopictus) merupakan vektor potensial (Hoedojo, 2008).

Insidensi DBD mengalami peningkatan di seluruh dunia dalam beberapa tahun terakhir. World Health Organization (WHO) melaporkan kejadian DBD meningkat secara drastis dalam 50 tahun terakhir dan infeksi virus ini terus meluas di berbagai negara. Data WHO menyatakan angka kejadian DBD di dunia sekitar 390 juta kasus infeksi dengue setiap tahunnya. Terdapat 3,9 miliar orang di dalam 128 negara yang beresiko terkena infeksi virus dengue (Hoedojo,2008; Alim L,2017)

Berdasarkan data dari

Kementerian Kesehatan Republik Indonesia menunjukkan angka kejadian DBD di Indonesia pada tahun 2015 sebanyak 129.650 kasus dengan jumlah kematian 1.071 orang, dan mengalami peningkatan pada tahun 2016 menjadi 204.171 kasus dengan jumlah kematian 1.598 orang, akan tetapi pada tahun 2017 kasus DBD mengalami penurunan menjadi 68.407 kasus, dengan jumlah kematian sebanyak 493 orang. Angka kesakitan DBD tahun 2017 menurun dibandingkan tahun 2016, yaitu dari 78,85 menjadi 26,10 per 100.000 penduduk. Namun, penurunan case fatality rate (CFR) dari tahun 2016 ke tahun 2017 tidak terlalu tinggi, yaitu $0,78 \%$ menjadi $0,72 \%$. Provinsi Riau merupakan salah satu provinsi dengan kasus DBD yang tinggi, dengan angka kesakitan 28,95 per 100.000 penduduk dan CFR 0,78\% pada tahun 2017 (WHO,2017; Pusat Data Kemenkes,2016; Kemenkes RI,2017)

Berdasarkan data Dinas Kesehatan Provinsi Riau pada tahun 2015 kejadian DBD di Provinsi Riau tercatat sebanyak 3.261 kasus dengan angka kematian sebanyak 20 orang dan terjadi peningkatan kejadian DBD pada tahun 2016 menjadi 4.066 kasus dengan angka kematian 39 orang (Pusat Data dan Informasi Kemenkes RI,2016). Kasus DBD di kota Pekanbaru pada tahun 2016 sebanyak 873 kasus dengan angka kematian 10 orang (Dinkes Provinsi Riau,2016). Pada tahun 2017 terjadi penurunan angka kejadian DBD di Kota Pekanbaru menjadi 598 kasus dengan angka kematian 3 orang yang tersebar di 12 kecamatan. Pada tahun 2018 dan 2019 kejadian DBD kembali meningkat di Provinsi Riau. Kabupaten Kampar merupakan salah satu dari 10 kabupaten yang mengalami peningkatan kasus pada tahun 2018 dan 2019

Kasus DBD memerlukan upaya penanggulangan dengan cara memutus salah satu rantai segitiga epidemiologi, diantaranya adalah dengan pengendalian vektor DBD yaitu nyamuk Ae. Aegypti ( Rahman MS,2016). Saat ini upaya pengendalian vektor dapat dilakukan 
dengan berbagai cara mulai dari cara alamiah hingga penggunaan insektisida. Pemerintah dan masyarakat umumnya lebih memilih menggunakan insektisida dalam upaya pengendalian populasi nyamuk vektor DBD. Hal ini menimbulkan masalah baru berupa munculnya resistensi Ae. Aegypti terhadap insektisida. (Prasetyowati,2016). Dengan demikian pemberantasan sarang nyamuk (PSN) tetap menjadi ujung tombak pemutusan rantai penularan.

Meskipun Program PSN telah dikampanyekan oleh pemerintah, namun kegiatan tersebut belum dapat terlaksana secara efektif di seluruh lapisan masyarakat. Salah satu hal penting dalam keberhasilan PSN adalah keberadaan Juru Pemantau Jentik (jumantik). Juru Pemantau Jentik (Jumantik) adalah anggota masyarakat yang secara sukarela memantau keberadaan jentik nyamuk Ae. aegypti di lingkungannya (Fidayanto R,2013). Mereka memiliki tanggung jawab untuk mendorong masyarakat melakukan PSN secara rutin. Jumantik berperan untuk meningkatkan kewaspadaan dan kesiapaan masyarakat menghadapi DBD. Peningkatan kapasitas bagi para jumantik memampukan mereka untuk menyebarkan informasi yang tepat dan benar tentang penanggulangan DBD. Namun demikian keterbatasa sumber daya menyebabkan tidak semua daerah memiliki jumantik yang aktif sehingga PSN di daerah tersebut tidak berjalan lancar. Melihat urgensinya keberadaan jumantik, pemerintah saat ini sedang giat giatnya mengkampanyekan adanya satu jumantik satu rumah.
Desa Buluh Cina Kabupaten Kampar merupakan salah satu kabupaten yang mengalami peningkatan kasus DBD tahun 2018 dan 2019. Wilayah tersebut merupakan desa binaan Fakultas Kedokteran Universitas Riau (FK UNRI) sejak tahun 2018. Setiap mahasiswa angkatan tahun 2018 merupakan anak asuh keluarga di desa tersebut. Berdasarkan studi awal didapatkan informasi bahwa jumantik di daerah tersebut tidak berjalan sesuai harapan. Hal ini disebabkan jumlah jumantik yang sedikit dan pada umumnya para jumantik merupakan warga yang bekerja. Hal ini berdampak pada kurang efektifnya PSN di wilayah tersebut yang dapat dilihat dari banyaknya tempat penampungan air yang terbiarkan di sekitar rumah penduduk. Berdasarkan hal tersebut muncul pemikiran untuk menggalakkan program satu rumah satu jumantik (SARUJU) di Desa Buluh Cina Kabupaten Kampar dengan partisipasi anak asuh masyarakat desa tersebut yang merupakan mahasiswa FK UNRI angkatan 2018 serta membina jumantik yang berasal dari anggota keluarga asli sehingga pemantauan jentik dapat dilaksanakan secara berkesinambungan.

\section{Metode Penerapan}

Kegiatan diawali dengan melakukan survey serta perijinan. Selanjutnya dilakukan pembekalan calon jumantik yang merupakan mahasiswa FK UNRI Angkatan 2018 sebanyak 140 orang dan merupakan anak asuh keluarga di desa binaan FK UNRI yaitu Kampung Pelita Medika 2 Buluh Cina,Kabupaten Kampar. Pembekalan terkait dengan informasi yang harus 
disampaikan kepada masing-masing keluarga angkatnya tentang gambaran umum DBD, cara penularan, gambaran klinis hingga komplikasinya serta cara pencegahan. Jumantik juga dibekali cara memantau jentik serta tekhnik pemberantasan sarang nyamuk. Calon jumantik nantinya akan bertugas menjadi jumantik I yang bertugas triwulan. Selanjutnya jumantik I nantinya akan membekali jumantik II di tiap rumah yang merupakan anggota keluarga dan akan bertugas secara berkesinambungan. Tim menyiapkan daftar ceklis pemantauan jentik yang harus diisi oleh calon jumantik, serta menjelaskan cara pengisiannya kepada calon jumantik. Tim beserta calon jumantik turun ke lokasi pengabdian. Masing-masing jumantik melaksanakan tugasnya di masing-masing rumah orang tua asuhnya. Jumantik melakukan survey jentik serta melakukan pemberantasan sarang nyamuk dengan $3 \mathrm{M}+$. Di samping itu jumantik melakukan penyuluhan kepada anggota keluarga tentang penularan, gambaran klinis hingga komplikasinya serta cara pencegahan. Penyuluhan juga terkait perilaku hidup bersih dan sehat terkait penularan DBD. Kepala keluarga diminta menunjuk salah satu anggota keluarga untuk menjadi jumantik II yang bertugas sehari hari. Jumantik I melakukan pembekalan kepada jumantik II tentang tekhnik survey jentik dan pemberantasan sarang nyamuk yang akan dilakukan sehari hari. Jumantik I dan II selalu melakukan koordinasi untuk mengoptimalkan hasil program.

Hasil survey oleh jumantik dianalisis untuk mendapatkan angka kepadatan jentik berdasarkan nilai
House index (HI), Container Index (CI) dan Breteau Index (BI) dan Angka Bebas Jentik (ABJ). Selanjutnya angka indeksasi tersebut dikelompokkan berdasarkan density figure (DF) menurut WHO.

\section{Hasil dan Pembahasan}

Buluh Cina merupakan desa yang terletak di Kecamatan Siak Hulu Kabupaten Kampar. Secara geografis letak Desa Buluh Cina dibatasi oleh beberapa desa. Terdapat beberapa desa yang berbatasan secara langsung diantaranya yaitu di sebelah timur berbatasan dengan Desa Pangkalanbaru, di sebelah barat berbatasan dengan Desa Tanjung Balam dan Desa Lubuk Siam, di sebelah selatan berbatasan dengan Desa Buluh Nipis sementara di sebelah utara berbatasan langsung dengan dengan Desa Baru. Keadaan alam daerah tersebut berupa daratan dan perairan, dimana sebahagian dari wilayahnya terdiri dari aliran sungai serta danaudanau. Desa Buluh Cina dipisahkan oleh Sungai Kampar yang posisinya membelah di tengah-tengah desa, yakni diantara Dusun I dan Dusun II dengan Dusun III dan Dusun IV.

Desa Buluhcina terdapat dua sarana transportasi yakni jalur darat dan jalur perairan. Untuk jalur darat bisa ditemput pada kondisi jalan yang beraspal. Sementara untuk jalur perairan dipergunakan sebagai jalur alternatif yang menghubungkan desa tersebut dengan desa tetangga. Jalur transportasi air di daerah hulu sungai menghubungkan desa tersebut dengan Desa Tanjung Balam, Desa Lubuk Siam, dan Desa Kampung Pinang (Kecamatan Perhentian Raja). Sementara untuk hilir 
sungai digunakan untuk menghubungkan desa tersebut dengan Desa Pangkalan Baru, Desa Buluh Nipis, dan Kuala Besako ke Kuala Kampar di Kabupaten Pelalawan.

Jarak Desa Buluhcina dengan ibu kota Propinsi Riau, Kota Pekanbaru dapat ditempuh dalam rentang waktu lebih kurang selama 1 jam perjalanan darat, dengan jarak tempuh mencapai 25 $\mathrm{km}$. Jarak desa tersebut cukup dekat jika ditempuh dari Ibu Kota Kecamatan Siak Hulu, yakni sekita $6 \mathrm{Km}$, atau lebih kurang 10 (sepuluh) menit saja. Sementara untuk jarak ke Ibu Kota Kabupaten Kampar yakni Bangkinang sejauh $83 \mathrm{Km}$, atau dapat ditempuh dengan waktu perjalanan selama 1,5 hingga 2 jam dengan menggunakan kendaraan roda dua maupun kendaraan roda empat.

Jumlah penduduk Desa Buluh Cina tercatat 1415 jiwa dan selalu meingkat setiap tahunnya. mata pencaharian penduduk kecamatan siak hulu yang tersebar adalah pertanian (petani sawah, pangan dan holtikultura, perkebunan, dan nelayan) 20,6 \% sedangkan mata pencaharian penduduk lainnya diluar pertanian adalah 79,4\%. Kondisi sanitasi lingkungan di Desa Buluh Cina perlu mendapatkan perhatian terutama pada musim penghujan yang menyebabkan banjir. Berdasarkan pengamatan banyak terdapat penampungan air yang berpotensi menjadi tempat berkembang biak nyamuk Aedes aegypti.

\section{Potensi Pengembangan}

\section{(Pemberdayaan) Masyarakat}

$$
\begin{array}{r}
\text { Keberhasilan suatu program } \\
\text { sangat bergantung pada partisipasi }
\end{array}
$$

masyarakat ( Hindarsih H,2017; Hendrakusumah E, 2017). Dalam upaya pengendalian DBD sangat diperlukan partisipasi aktif dari masyarakat untuk memutus rantai penularan. Ujung tombak pemberantasan DBD saat ini dititikberatkan pada pengendalian vektor yakni nyamuk Aedes aegypti dengan cara pemberantasan sarang nyamuk (PSN). Kegiatan PSN bertahun tahun selalu dikampanyekan untuk terus diberdayakan di masyarakat, namun selalu terdapat kendala dan rendahnya partisipasi masyarakat. Melalu kegiatan pengabdian SARUJU ini motor utamanya adalah anggota keluarga yang ditunjuk menjadi jumantik dari setiap rumah di Desa Buluh Cina dibantu oleh mahasiswa FK UNRI Angkatan 2018 yang menjadi anak asuh masyarakat di desa tersebut. Keberhasilan kegiatan ini sangat tergantung dari partisipasi aktif dari para jumantik karena kegiatan ini harus dilaksanakan berkesinambugan.

Partisipasi jumantik setiap rumah diawali dengan gerakan saruju yang dilaksanakan oleh mahasiswa Angkatan 2018 yang telah dilatih sebelumnya. Mahasiswa tersebut merukana jumantik 1 yang akan menunjuk jumantik 2 dari tiap rumah. Jumantik 1 berkewajiban mentransfer ilmunya kepada jumantik 2 agar secara regular jumantik 2 dapat melakukan survey jentik dan pemberantasan nyamuk yang komprehensif.

\section{Solusi Pengembangan}

\section{(Pemberdayaan) Masyarakat}

Kegiatan SARUJU merupakan bagian dari kegiatan PSN yang merupakan modifikasi dari program jumantik yang telah lama ada. Jumantik 
merupakan singkatan dari juru pemantau jentik yang merupakan anggota masyarakat yang secara sukarela memantau keberadaan jentik nyamuk di lingkungannya serta melakukan pemberantasan sarang nyamuk secara rutin. Selama ini kegiatan survey jentik yang dilaksakan oleh jumantik sering mendapatkan banyak kendala yang salah satunya disebabkan kurangnya jumlah jumantik dan tidak aktifnya jumantik yang telah ditunjuk. Berdasarkan hal tersebut untuk mengefektifkan kerja jumantik perlu dibentuk jumantik yang ada di setiap rumah. Dengan adanya jumantik di setiap rumah diharapkan kegiatan survey jentik dan pemberantasan nyamuk lebih efektif. Dalam pemberantasan DBD diperlukan mawas diri terhadap keberadaan jentik nyamuk di rumah sendiri melalui gerakan satu rumah satu jumantik (SARUJU). Di samping jumantik di tiap rumah perlu juga dibentuk jumantik di tiap sekolah yang mana petugas jumantiknya adalah murid di sekolah tersebut.

Gerakan SARUJU merupakan upaya gerakan yang sangat efektif, dimana setiap rumah harus memiliki agent of change untuk mengubah perilaku dan mengaktifkan gerakan $3 \mathrm{M}+$ yaitu mengubur, menguras, menutup dan plus melipat baju yang bergantungan, mendaur ulang barang bekas, menabur abate dan lain lain. Jumantik bertugas memantau jentik nyamuk yang ada di sekeliling tempat tinggal terutama di tempat-tempat yang bisa menjadi sarang nyamuk seperti bak mandi, kaleng, drum dan lain-lain. Kegiatan plusnya adalah menaburkan bubuk larvasida, menggunakan obat nyamuk, menggunakan kelambu, memelihara ikan pemangsa jentik, menanam tanaman pengusir nyamuk dan menghindari kebiasaan menggantungkan baju.

Selain 3M+ yang harus dilakukan jumantik, dia juga bertindak sebagai agent of change dalam hal perilaku hidup bersih dan sehat. Jumantik diharapkan menjadi pelopor dalam hal yang berkaitan dengan pencegahan DBD. Jumantik secara regular wajib melakukan survey jentik untuk menilai kepadatan jentik, sehingga dapat dievaluasi nilai house index (HI), container index (CI) serta breteau index (BI).

Gerakan SARUJU diawali dengan pembentukan jumantik yang merupakan mahasiswa FK UNRI Angkatan 2018 dan merupakan anak asuh keluarg di Desa Buluh Cina selaku Kampung Pelita Medika atau desa binaan FK UNRI. Jumantik mahasiswa yang disebut sebagai jumantik I dilatih oleh narasumber dari KJF Parasitologi secara komprehensif terkait pencegahan DBD dan pengisian formulir entomologi. Selanjutnya Jumantik I turun ke tiap rumah orang tua asuhnya untuk melakukan survey jentik dan edukasi 3M+ pada anggota keluarga. Selanjutnya jumantik I bersama kepala keluarga menyepakati salah satu anggota keluarga untuk menjadi jumantik, yang selanjutnya disebut jumantik II, sehingga tiap rumah saat ini memiliki dua orang jumantik. Jumantik I berkewajiban melakukan in house training tentang pencegahan DBD serta pengisian formulir entomologi kepada jumantik II. Secara regular jumantik II yang berkewajiban melakukan gerakan 
evaluasi jentik dan wajib melaporkan kepada jumantik I. selanjutnya hasil yang didapatkan oleh jumantik I akan dikumpulkan untuk dianalisis dan dievaluasi kepadatan larva tiap periodenya.

\section{Tingkat Ketercapaian Sasaran Program}

Tujuan gerakan SARUJU adalah memutus rantai penularan DBD terutama memutus penularan melalui vektor. Indikator ketercapaian program adalah sebagai berikut:

a. Jangka pendek

Meningkatnya pengetahuan jumantik tentang gerakan pencegahan DBD yang komrehensif, melakukan PSN serta melakukan survey jentik dan mengisi formulir entomologi. Melalui kegiatan pengabdian kepada masyarakat ini jumantik yang telah ditetapkan baik jumantik I dan II telah memahami hal hal yang berkenaan dengan pencegahan DBD yang ditandai dengan telah terlaksananya kegiatan survey jentik dan PSN tahap 1. Kegiatan survey jentik dapat dilihat pada gambar 1

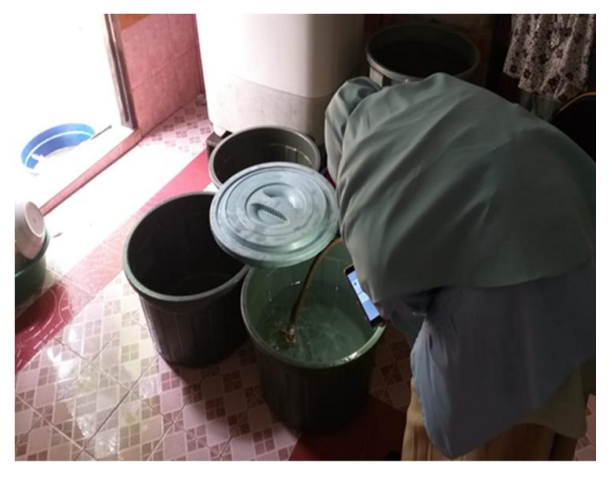

Gambar 1. Kegiatan Survey Jentik

b. Jangka Menengah

Menurunnya angka kepadatan jentik yang dinilai dari HI, CI dan BI.
Angka kepadatan jentik belum dapat dievaluasi saat ini, namun baseline angka kepadatan jentik di daerh tesebut telah didapatkan dari kegiatan survey tahap I. Adapun baseline angka kepadatan jentik di Desa Buluh Cina dapat dilihat pada table 1 .

Tabel 1. Indikator HI,CI,BI dan ABJ

\begin{tabular}{lll}
\hline $\begin{array}{l}\text { Indikator } \\
\text { Indeks }\end{array}$ & Angka & Kategori \\
\hline HI & $38 \%$ & Tinggi \\
CI & $24,39 \%$ & Tinggi \\
BI & $50 \%$ & Tinggi \\
ABJ & $61,9 \%$ & Tinggi \\
\hline
\end{tabular}

Berdasarkan angka kepadatan tersebut selanjutnya dikelompokkan tingkat kepadatan berdasarkan density figure (DF) berdasarkan WHO. Berdasarkan tingkat DF didapatkan angka HI dengan DF 6; CI dengan DF 6 dan BI dengan DF 6. Berdasarkan angka DF menunjukkan kepadatan larva di daerah tersebut termasuk tinggi.

c. Jangka Panjang

Menurunnya kejadian DBD di Desa Buluh Cina Kabupaten Kampar. Tujuan jangka panjang belum dapat dinilai saat ini akan tetapi dengan kegiatan PSN yang berkesinambungan diharapkan tujuan tersebut akan tercapai.

\section{Kesimpulan dan Saran}

Telah dilaunching kegiatan satu rumah satu jumantik (SARUJU) di Desa Buluh Cina Kabupaten Kampar dan telah diadakan survey jentik tahap pertama. Tingkat kepadatan jentik nyamuk berdasarkan House Index, Container Index dan Breteau Index di Desa Buluh 
Cina tergolong tinggi. Perlu pemantauan berkala terhadap kinerja jumantik di Desa Buluh Cina Kabupaten Kampar. Di samping itu perlu diperluas kegiatan SARUJU ini sampai ke sekolah sekolah dengan melibatkan siswa di sekolah tersebut.

\section{Daftar Pustaka}

Alim L, Heryani F, Isiana. Tingkat Kepadatan Jentik Nyamuk Aedes aegypti pada Tempat Penampungan Air Controllable Sites dan Disposable Sites di Sekolah Dasar Kecamatan Banjarbaru Utara. Berkala Kedokteran 2017;13(1):8 [dikutip pada 27 Agustus 2018]. Diunduh dari: https://ppjp. ulm.ac.id/journal/index.php/jbk/artic le/view/3434

Astuti RD, Ismawati, Siswanti LH, Suhartini A. Sebaran Vektor Penyakit Demam Berdarah (Aedes aegypti) di Kampus Universitas Islam Bandung. Global Medical and Health Communication. 2016;4(2):83 [dikutip pada 27 Agustus 2018]. Diunduh dari: https://ejournal.unisba.ac.id/index.p hp/gmhc/ article/view/1602

Chandra, Aryu. Demam Berdarah Dengue: Epidemiologi, Patogenesis, dan Faktor Risiko Penularan. Aspirator. 2010;2(2):110-12 [dikutip pada 27 Desember 2018]. Diunduh dari: ejournal.litbang.depkes.go.id/index/ php/ aspirator/article/view/2951

Dinas Kesehatan Provinsi Riau. Profil Kesehatan Provinsi Riau 2016. 2017:36-9 [dikutip pada 2 November
2018]. Diunduh dari: www.depkes.go.id

Febiantoro Y, Alvira L, Hanif AH, Hidayat BA, Juita N, Wahyuningsih NE. Precent Aedes Pump Sebagai Alat Untuk Memutus Siklus Hidup Nyamuk Aedes aegypti dan Meningkatkan Efidiensi Pembersihan Air di Bak Mandi Skala Rumahan. Jurnal Ilmiah Mahasiswa. 2012;2(2):72-3 [dikutip pada 5 Januari 2019]. Diunduh dari: https://ejournal.undip.ac.id/index.ph p/jim /article/view/10751

Fidayanto R, Susanto H, Yohanan A, Yudhastuti. Model Pengendalian Demam Berdarah Dengue. Jurnal Kesehatan Masyarakat Nasional. 2013;7(11):527-8 [dikutip pada 25 Februari 2019]. Diunduh dari: journal.fkm.

ui.ac.id/kesmas/article/view/366

Harrington LC, Edman JD, Scott TW. Why Do Female Aedes aegypti (Diptera: Culicidae) Feed Preferentially and Frequentylon Human Blood. Journal of Medical Enotomology. 2001;38(3):411 [dikutip pada 24 Februari 2019]. Diunduh dari: https://www.ncbi.nlm.nih.gov/m/pu bmed/ 11372967/

Hendri J, Santya RN, Prasetyowati H. Distrbusi dan Kepadatan Vektor Demam Berdarah Dengue Berdasarkan Ketinggian Tempat Di Kabupaten Ciamis Jawa Barat. Jurnal Ekologi Kesehatan. 2015;14(1):17-26 [dikutip pada 25 Januari 2019]. Diunduh dari: https://media.neliti.com/media/ publications $/ 81582$ 
Hendrakusumah E. The Management of Independently Simple Water Purification in Theory and Practice Community Level. Ethos: Jurnal Penelitian dan Pengabdian Vol 5 no 1. 2017

Herdady MR, Mustarichie R. Artikel Riview: Perkembangan dan Potensi Vaksin DBD dari Berbagai Negara. Farmaka Sumplemen. 2018;16(3):107 [dikutip pada 24 Februari 2019]. Diunduh dari: jurnal.unpad.ac.id/farmaka /article/view/17415/pdf

Herry G, editor. Divisi Infeksi dan Penyakit Tropis. Bandung:Sagung Seto;. 2012.h.336-50

Hindersah H, Agustina IH, Idratno I.

Pembelajaran Tata Bangunan dan Lingkungan di Desa Cikole Kecamatan Lembang Kabupaten Bandung Barat. Ethos: Jurnal Penelitian dan Pengabdian Vol 5 no 2, Juni 2017

Hoedojo R, Zulhasril. Insektisida dan Resistensi. Dalam: Gandahusada S, Ilahude HD, Pribadi W. Parasitologi Kedokteran. Edisi Keempat. Jakarta 2008

Kementerian Kesehatan Republik

Indonesia. Profil Kesehatan Indonesia Tahun 2017 [dikutip pada 2 November 2018]. Di unduh dari www.depkes.go.id.

Pramestuti N, Djati AP. Distribusi Vektor Demam Berdarah Dengue Daerah Perkotaan dan Perdesaan di Kabupaten Banjarnegara. Buletin Penelitian Kesehatan. 2013;41(3):164-9 [dikutip pada 12 Januari 2019]. Diunduh dari: ejournal.litbang.depkes.goid/index.p hp/BPK/article/view/3287/3281
Prasetyowati, H, Gianjar A. Penggunaan Insektisida Rumah Tangga dalam Pengendalian Populasi Aedes aegypti di Daerah Endemis Demam Berdarah Dengue (DBD) di Jakarta Timur. Aspirator. 2016;8(1):30 [dikutip pada 15 November 2018]. Diunduh dari:

https://www.neliti.com/publications/ 56499

Pusat Data dan Informasi Kementrian Kesehatan Republik Indonesia. Situasi DBD di Indonesia. 2016:1-4 [dikutip pada 27 Agustus 2018]. Diunduh dari: www.depkes.go.id.

Radji, Maksum. Imunologi dan Virologi. Jakarta:ISFI Penerbitan; 2010.h.2859

Rahayu DF, Ustiawan A. Identifikasi Aedes aegypti dan Aedes albopictus. BALABA. 2013;9(1):7-10. [Di kutip pada 27 Desember 2018]. Di unduh dari ejournal.litbang.depkes.go.id/index. php/blb/article/download/3269/3265

Rahman MS, Sofiana L. Perbedaan Status Kerentanan Nyamuk Aedes Aegypti Terhadap Malathion Di Kabupaten Bantul Yogyakarta. Jurnal Kesehatan Masyarakat Universitas Negeri Semarang. 2016:11(2):2-7 [dikutip pada 15 November 2018]. Diunduh dari: http://journal.unnes.ac.id/nju/index. php /kemas

Sari, Muna. Perkembangan dan Ketahanan Hidup Larva Aedes egypti Pada Beberapa Media Air Yang Berbeda. [Skripsi]. Lampung: Universitas Lampung; 2017 [dikutip pada 5 januari 2019]. Diunduh dari: digilib.unila.ac. id/26414/2/

https://doi.org/10.29313/ethos.v7i2.4412 
104 | Suri Dwi Lesmana, et al.

Suhendro, Nainggolan L, Chen K, Pohan

HT. Demam Berdarah Dengue.

Dalam: Setiati S, Alwi I, Sudoyo AW, Simadibrata M, Setiyohadi B, Syam AF, editor. Buku Ajar Ilmu Penyakit Dalam. Edisi ke-6. Jakarta:Interna Publishing; 2014.h.539.

Supartha, I Wayan. Pengendalian Terpadu Vektor Virus Demam Berdarah Dengue, Aedes aegypti(Linn.) dan Aedes albopictus (Skuse) (Dipetra: Culicidae). 2017:10-5 [dikutip pada 25 Februari 2019]. Diunduh dari: http://researchgate.net/publication/2 37671079

Suyanto, Darnoto S, Astuti D. Hubungan Pengetahuan dan Sikap dengan Praktek Pengendalian Nyamuk Aedes aegypti di Kelurahan Sangkrah Kecamatan Pasar Kliwon Kota Surakarta. Jurnal Kesehatan. 2011;4(1):4-6 [dikutip pada 5 Januari 2019]. Diunduh dari: https://publikasiilmiah.ums. ac.id/bitstream/handle/11617/2930

World Health Organization. Dengue and Severe Dengue. 2017 [dikutip pada 27 Agustus 2018]. Diunduh dari: http://www.who.int/mediacentre/fac tsheets /fs117/en.

Zulhasril, Lesmana SD. Deteksi

Resistensi Aedes aegypti terhadap Insektisida Organofosfat di Tanjung Priok Jakarta Utara dan Mampang Prapatan Jakarta Selatan dengan Microplate Assay. Majalah Kedokteran FK UKI. 2010;27(3):97106 